\title{
Social Intelligence and Equality
}

The democratic faith in human equality is belief that every human being, independent of the quantity or range of his personal endowment, has the right to equal opportunity with every other person for development of whatever gifts he has. (LW14: 227)

We talk a great deal about democracy as equality of opportunity and then we adopt a system of private ownership of opportunities that makes our boast a farce and a tragedy. (LW11:256)

Throughout his life and beyond it, Dewey's work on creative democracy has largely been criticized as being complicit with capitalism or being toothless in its opposition to capitalism. We have already seen that Bertrand Russell (1922) and Lewis Mumford (1926) argued that pragmatism was an expression of the material excesses of American capitalism and the Gilded Age. The Frankfurt School would echo similar critiques of the complicity between Dewey, his fellow classical pragmatists and the capitalist social order (Lukacs 1971; Horkheimer 1972; Adorno 1973). Reinhold Niebuhur (1932) would label Dewey as a politically apathetic thinker, who had lurched towards believing in the idea of a self-correcting form of reason - a thought rearticulated by C. Wright Mills in the 1960s when he would declare that Dewey's work lacked an account of the power structures of the modern capitalist social order (Mills 1964). Even sympathetic interlocutors like Robert Westbrook (1991, 2005), Michael Eldridge (1998) and Cornel West (1989) appear to suggest that Dewey provided far too few concrete practical means to achieve his own democratic ends. As Richard Bernstein (2010: 87) puts it, Dewey's idea of democracy as way of life 
argues for a 'social goal based on an inclusive plan' but fails to spell out the details of such an 'inclusive plan.'

Both sets of these claims seem to miss the mark. As we have seen, Dewey certainly was no apologist for liberal capitalism at home or abroad. And whilst Dewey was often unforthcoming or rather unwilling to offer definitive blueprints for how to achieve creative democracy, it is also unfair to say that Dewey left behind few concrete practical means to achieve his own democratic ends. Dewey thought that the collapse of European democracy into totalitarianism and the eclipse of the public in America transpired because democratic habits were no longer part of the 'bone and blood of the people in daily conduct of its life'. To this end, Dewey put forward a whole raft of reforms that he believed would help democracy as a way of life become part of the 'fibre' of the people (LW11: 225). These included reforms such as new approaches to the American economy, public education, the role of social science and the social scientist as an 'expert', media regulation and the role of the arts in democracy. ${ }^{2}$

All of these concrete proposals deserve attention and serve as an example of how Dewey believed reforms could bring forth a greater array of democratic habits that would facilitate the practice of creative democracy. However, for the purposes of our exposition of a 'global' Dewey, in this and the next chapter, I want to focus on the concrete lessons Dewey put forward on how to achieve democracy at home and abroad and how both spheres of democracy were intertwined. In this chapter, I specifically want to focus on Dewey's ideas about the economic reforms needed to facilitate what he called social intelligence in the midst of a liberal-capitalist order that stunted the intelligence of its citizens. Moreover, I want to focus on Dewey's ideas about how the Great Society and its regime of bourgeois democracy needed to shift to a form of democratic socialism to achieve the goal of becoming a Great Community. These economic reforms not only seemingly laid the grounds for all of Dewey's other reforms but were also based on the need to provide the ethical commitment at the heart of democracy as a way of life and the grounds for an expanded social intelligence both 
within and beyond the nation state. This chapter will therefore outline how Dewey believed that the Great Society was to be regulated not only to avoid the mutual destruction of humanity but also to succeed in harnessing 'available human energy' (LW13: 312).

To illustrate the above, the chapter will proceed through four movements of argument. The first section will outline how Dewey's idea of creative democracy was based upon a form of deliberation he called social intelligence and how social intelligence is essentially an adoption of the 'scientific attitude of the mind' in moral and political matters. The second section will outline how Dewey believed liberal capitalism was unable to support social intelligence and needed replacing with a form of democratic socialism. The third section will outline how Dewey's call for democratic socialism was animated by his view about the relationship between economic inequality and political equality within the Great Society. The final section will highlight how Dewey's views on economic and political equality translate into an argument for an extension of global egalitarianism that would allow all nations of the world to pursue the democratic way of life.

\section{The habits of social intelligence}

As we have seen, the emergence of the Great Society fundamentally altered reality for citizens in the United States of America and beyond. This process had been set in motion by the industrial and technological revolutions, which had been driven by modern science and ushered in modernity. Dewey highlighted the fact that whilst the physical forces of the industrial-technological revolutions had 'revolutionised the face of the globe', the political and moral 'ideas and ideals that rule us are still largely those of a pre-scientific, pre-industrial, pre-technological age. With this in mind, Dewey declared that it was understandable, even if one could not sympathize with such views, why reactionary and conservative ideologies clamoured for a return to simpler conditions'. These viewpoints resorted to a 'mixture of exhortation 
and with reliance upon traditions, habits, institutions, which were adjusted to bygone conditions. And although they clamoured for the impossible - a return to political isolation - the rise of fascism, Nazism and state totalitarianism was 'no accident' but the logical conclusion of a disjunction between our political ideals and the reality of the Great Society (LW17: 454, 459).

The problem of the Great Society and its politics, Dewey contended, was that monolithic theories and ideologies of social action tended to have 'ready-made' answers to a context that was prone to changing and which demanded new solutions. However, if Dewey (LW1: 358) was adamant that the industrial-technological revolution was largely, if not wholly, responsible for the two world wars and the threat of another of ultimate destructiveness', he was also adamant about the 'potential alliance between scientific and democratic method and the need of consummating this potentiality' in tackling the problems and publics generated by the Great Society (LW13: 135). Moreover, Dewey believed that the 'crisis in democracy' demanded the 'substitution of intelligence that is exemplified in scientific procedure for the kind of intelligence that is now accepted' (LW11: 51). This alliance between the scientific and the democratic method is what Dewey calls 'social intelligence'.

To understand Dewey's idea of social intelligence, we must first recall Dewey's ideas of creative democracy and democratic community that we explored in Chapter 1. Creative democracy points towards the perpetual adaption of social institutions, including democratic institutions and practices themselves, as new publics are engendered by social change. This is founded on the ethical commitment of democracy as a way of life to the principle that those who are affected by social institutions should have an equality of opportunity to contribute to the production and management of those institutions. The balanced equality of democracy as a way of life and its focus on collective problem-solving highlights Dewey's faith in a deliberative (conference, consultation, negotiation and persuasion) form of political settlement and the establishment of a democratic community. 
What, then, is the role of social intelligence in creative democracy and in the maintenance of the democratic community? The answer centres on the form of deliberation within the democratic community. Dewey cautioned that public discussion and comparison of ideas alone were inherently too weak to meet the problems brought about by the movements of the Great Society (LW11: 50-2). ${ }^{3}$ Social intelligence is thus not simply the practice of democratic deliberation, but rather a certain way of democratically practising deliberation. Quintessentially, social intelligence attempts to adapt the 'experimental method' of natural science in the arena of human relations. This does not mean that particular techniques of natural science were to be simply transposed into social contexts or that laboratory experimentation was to be carried out on society at large. Whilst Dewey did not discount the use of such scientific methods in social affairs, he primarily saw the key part of social intelligence as centring on the transposition of the 'attitude of the mind exemplified in the conquest of nature by experimental science' into 'social affairs' (LW9: 108). Social intelligence therefore attempts to utilize elements of natural science's 'attitude of the mind' to promote an array of habits, a personal way of living, which perpetuates democracy as a way of life in the day-to-day lives of citizens (LW7: 329-30).

In the first instance, Dewey outlines that social intelligence would see individuals possess 'democratic habits of thought and action', which stem from the scientific attitude of the mind, and that they would practise such methods in 'all social relationships' (LW11: 225). Dewey outlines this 'distinctive type of disposition and purpose' as habits of thought and action that would promote:

... willingness to hold beliefs in suspense, ability to doubt until evidence is obtained; willingness to go where evidence points instead of putting first a personally preferred conclusion; ability to hold ideas in solution and use them as hypotheses to be tested instead of dogmas to be asserted; and (possibly the most distinctive of all) enjoyment of new fields for enquiry and of new problems. (LW13: 166)

Through such habits, Dewey contends, members of a society can substitute the utilization of unquestioned moral truths, such as class 
interests, pride and prejudice, commands of the state, constitutions or traditions, with a process of social intelligence that utilizes the 'experimental method' of forming social policy and morality as 'cooperative undertakings' between members of a community (LW7: 329; LW14: 228).

The term 'experimental method' may erroneously suggest Dewey's embracement of moral relativism or the belief that all past moral precedents that provide the basis for established social policy are to be lightly discarded. However, the overriding point of the adoption of the scientific attitude to the appraisal of moral conflict is the belief that there can be no assumption of an a priori truth that would automatically adjudicate moral conflict or provide the basis for social policy. Eschewing moral relativism, the experimental method places its faith in demonstrable evidence rather than dogmatic moral absolutes when appraising moral conflict and the merits of social policy. In the light of this, an experimental method of forming social policy and morality is simply how members of a society, who share a common embracement of the scientific attitude, collectively appraise moral conflict and the merits of respective social policy. Dewey defines the experimental method as a 'reflective morality' that:

... demands observation of particular situations, rather than fixed adherence to a priori principles; that free enquiry and freedom of publication and discussion must be encouraged and not merely grudgingly tolerated; that opportunity at different times and places must given for trying different measures so that their effects maybe be capable of observation and of comparison with one another. (LW7: 329)

In this scenario, the machinations of the cultural matrix and social policy are to be approached in terms of an analysis of cause and effect and means and consequences (LW11: 52). Just as past principles, precedents or points of authority are used in natural science, social policies are to be used as 'working hypotheses' which, based on the knowledge of past experience, act as tools that help us manage material culture towards desired ends. Established social policies are to be no 
more easily discarded than established scientific principles but they are to be continually subject to 'constant' and 'well-equipped' inquiry, observation and reflection upon the consequences they entail. Dewey dubs such an approach 'experimental', however, because on the back of such observation and reflection, which may bring to light newly discovered evidence or conditions within the cultural matrix that lead to doubt over their soundness or acceptability, all social policies and the moral values which engender them are to be open to revision or alteration (LW7: 329-30). ${ }^{4}$

Social intelligence therefore mandates that deliberation within the democratic community is not to be a fight over notions of antecedent and independent conceptions of morality or social policy but rather the experimental formation of moral value and social policy in response to evidence. The underlying premise of this process is that 'day-to-day working together with others' is the best solution to social problems. As Kloppenburg (1994: 79) contends, Dewey's idea of the democratic community and the use of social intelligence replicate what Dewey saw as the chief tenets of the scientific community:

No scientific inquirer can keep what he finds to himself or turn it to merely private account without losing his scientific standing. Everything discovered belongs to the community of workers. Every new idea and theory has to be submitted to this community for confirmation and test. There is an expanding community of cooperative effort and of truth. (LW5: 115)

Under the remit of social intelligence, differing or conflicting moral parties do not merely deliberate their positions but actually explore their conflict as a problem to be solved by embracing the scientific attitude and the experimental method of forming social policy and morality. This means not only having the willingness to learn from the moral positions and evidence about the machinations of society and associated behaviour put forward by different publics, but also having the willingness to surrender such a conflict to constant and well-equipped inquiry and observation, and then for both sides to cooperate in solving such moral conflict: 
even when needs and ends or consequences are different for each individual, the habit of amicable cooperation - which may include, as in sport, rivalry and competition - is itself a priceless addition to life. To take as far as possible every conflict which arises - and they are bound to arise - out of the atmosphere and medium of force, of violence as a means of settlement into that of discussion and of intelligence is to treat those who disagree - even profoundly - with us as those from who we may learn, and in so far, as friends ... To cooperate by giving difference a chance to show themselves because of the belief that the expression of difference is not only a right of the other persons but is a means of enriching one's own life experience, is inherent in the democratic personal way of life. (LW14: 228)

Dewey's idea of creative democracy must therefore be seen as an evolutionary form of democracy predicated upon the widespread use of social intelligence in the appraisal of moral conflict over social policy. It was the maintenance of the democratic community through the methods of social intelligence, Dewey believed, which would allow moral conflicts and the resultant social policy decisions to be settled in the 'widest possible contribution of all - or at least the great majority' (LW11: 56).

The obvious question that follows from this discussion is this: Why did Dewey believe social intelligence to be the best method for approaching moral and political conflict? Dewey believed that social intelligence, whilst not a panacea for all social problems, held the greatest hope of bringing 'order and even abundance to societies plagued by strife and uncertainty' (Gouinlock 1990: 268). In the first instance, this was based on the non-absolutism of social intelligence allowing for all moral positions to be voiced, heard and evaluated through social intelligence. In this sense, social intelligence provided publics with the best method of voicing grievances and collaborative process of political settlement that avoided the recourse to violence and coercive control:

When democracy openly recognizes the existence of problems and the need for probing them as problems as its glory, it will relegate political 
groups that pride themselves upon refusing to admit incompatible opinions to the obscurity which already is the fate of similar groups in science. (LW13: 135)

Dewey pushed this position even further by suggesting that 'social control effected through organised application of social intelligence' was the only form of political settlement that could deal with 'existing evils without landing us firmly in some form of coercive control from above and outside' (LW 13: 320).

Dewey's faith in a form of creative democracy through social intelligence was also based on what he saw as the productive gains the scientific community had bequeathed to humanity and the possible gains it could provide for humanity within the sphere of moral and political matters. This process within science seemingly validated the co-operative inquiry of social intelligence:

The contrast between the state of intelligence in politics and in the physical control of nature is to be taken literally. What has happened in this latter is the outstanding demonstration of the meaning of organized intelligence. The combined effect of science and technology has released more productive energies in a bare hundred years than stands to the credit of prior human history in its entirety... The stationary engine, the locomotive, the dynamo, the motorcar, turbine, telegraph, telephone, radio and moving picture are not the products of either isolated individual minds nor of the particular economic régime called capitalism. They are the fruit of methods that first penetrated to the working causalities of nature and then utilized the resulting knowledge in bold imaginative ventures of invention and construction. (LW11: 52)

Dewey located the revolutions of science that in turn led to the industrial-technological revolutions as revealing the social nature of intelligence. In this regard, science highlighted how intelligence was a 'social asset' with a public origin based on social co-operation (LW11: 48). Moreover, science and its sense of community highlighted to Dewey that allowing individuals to share in the fruits of community 
would allow the effective intelligence of all to rise considerably. Indeed, Dewey stated that in 'a social medium in whose institutions the available knowledge, ideas and art of humanity were incarnate the average individual would rise to undreamed of heights of social and political intelligence' (LW11: 50). Beyond this, however, science also highlighted how the social nature of intelligence could lead to unthinkable advancements across society when teamed with the experimental method of approaching problems through the cooperative undertakings. Dewey's hope was that the democratic community could realize the method of the scientific community through using social intelligence, and in doing so, correct the failure to utilize 'human power' in the same way science had utilized nature to realize productive energies:

The general adoption of the scientific attitude in human affairs would mean nothing less than a revolutionary change in morals, religion, politics and industry. The fact we have limited its use so largely to technical matters is not a reproach to science, but to the human beings who use it for private ends and who strive to defeat its social application for fear of destructive effects upon their power and profit. A vision of a day in which the natural science and the technologies that flow from them are used as servants of a humane life constitutes the imagination that is relevant to our own time. (LW5: 115)

This may all sound like wishful thinking and Dewey was willing to admit that he himself may be exaggerating the power of co-operation vis-à-vis ideas of class conflict or the inherent evil within humanity. But in the context of the greatest crisis of liberal democracy and the rise of totalitarianisms, Dewey contended that social intelligence was 'worth a trial' and that 'illusion for illusion', this particular one may be better 'than those humanity has usually depended upon' (LW9: 108). More to the point, Dewey was adamant that a society and culture that permitted science to destroy traditional values but which distrusted its power to create new ones was a culture which was 'destroying itself' (LW13: 172). ${ }^{5}$ 


\section{The planning society}

Dewey believed that social intelligence highlighted that humans were capable of 'intelligent' judgement and action, both individually and collectively, when appraising social problems and forming social policy (creative democracy), if equipped with an equality of communication and participation in democratic life (democracy as a way of life), the right intellectual sensibility and habits (scientific attitude) and the free play of facts and ideas (experimental method). This was the co-joining of the democratic method with the scientific method. However, Dewey was certainly no believer that bourgeois democracy was hospitable to such a method or that citizens widely possessed democratic habits of social intelligence. As we encountered in Chapter 3, Dewey's take on bourgeois democracy and its pernicious effects on the 'intelligence' of the masses are quite clear. The hegemony of finance capitalism and its creation of vast material and cultural inequality stunted any chance of creative democracy through limiting both the participation and intelligence of the masses. This not only neglected the ethical commitment of the democratic as a way of life but also failed to utilize them as a resource for the practice of social intelligence. As Dewey outlines, bourgeois democracy gave no opportunity for the great mass of people:

... to reflect and decide upon what is good for them. Others who are supposed to be wiser and who in any case have more power decide the question for them and also decide the methods and means by which subjects may arrive at the enjoyment of what is good for them. This form of coercion and suppression is more subtle and more effective than is overt intimidation and restraint. When it is habitual and embodied in social institutions, it seems the normal and natural state of affairs. The mass usually become unaware that they have a claim to a development of their own powers. Their experience is so restricted that they are not conscious of restriction. It is part of the democratic conception that they as individuals are not the only sufferers, but that the whole social body is deprived of the potential resources that should be at its service. (LW11: 218-19) 
Dewey argued that the 'ultimate' institution, which could help mitigate the lack of democratic habits amongst the masses, was education and educational reform. Education 'more than other single agency, is concerned with the development of free inquiry, discussion and expression' (LW11: 253). However, Dewey did not believe that bourgeois democracy and the results it generated could be patched up 'here and there' through sporadic reforms to areas such as education. Instead, what was first and foremost needed was the recognition of the 'moral, emotional and intellectual effect' the day-to-day workings of the political economy of bourgeois democracy had upon all citizens:

... every one who reflects upon the subject admits that it is impossible that the ways in which activities are carried on for the greater part of the waking hours of the day; and the way in which the shares of the individuals are involved in the management of affairs in such a matter as gaining a livelihood and attaining material and social security, can only be a highly important factor in shaping personal dispositions; in short, forming character and intelligence. (LW11: 221)

In order to facilitate the spread of democratic habits of social intelligence amongst the masses, it was imperative, Dewey argued, that the 'profit system' of capitalism be reoriented to one which would realize that the 'ultimate problem of production is the production of human beings' (LW13: 318). To accomplish this, Dewey put forward the idea of reorientating the American economy around a form of democratic socialism. This centred on adopting various ideas from the 'British Labour Party and Social Democratic Parties of Europe' and required the socialization of the 'commanding heights of the economy' through creating publics works, enacting taxes that could deliver a thorough redistribution of wealth and the nationalization of industries (LW9: 289-90). However, Dewey envisioned a socialized economy that was not simply a form of state socialism. A socialized economy was to provide the platform that would facilitate creative democracy through the practice of social intelligence. This move for economic freedom was thus geared towards securing the cultural freedom needed to perpetuate social intelligence (LW11: 254). This included the 
aforementioned reforms to education, the media and the arts, but also an increased workplace democracy and a remodeling of the state and its political democracy towards resolving moral conflicts between publics (Westbrook 1991: 457).

The twining of a socialized economy with participatory democracy provided the grounds for what Dewey saw as the difference between the 'planning society' of democratic socialism vis-à-vis the 'planned society' of bourgeois democracy and its communist and fascist alternatives. A planning society was essentially another name for what Dewey believed would be the practices of creative democracy in the Great Community. Such a society would not just drift from problem to problem but actively use social intelligence in order to practise creative democracy and perpetuate the future use of social intelligence through a diffusion of democratic habits across society:

What claims to be social planning is now found in Communist and Fascist countries. The social consequence is complete suppression of freedom of inquiry, communication and voluntary association, by means of a combination of personal violence, culminating in the extirpation, and systematic partisan propaganda. The results are such that in the minds of many persons the very idea of social planning and of the violation of the integrity of the individual are becoming intimately bound together. But an immense difference divides the planned society from a continuously planning society. The former requires fixed blueprints imposed from above and therefore involving reliance upon physical and psychological force to secure conformity to them. The latter means the release of intelligence through the widest form of cooperative give-and-take. The attempt to plan social organization and association without the freest possible play of intelligence contradicts the very idea of social planning. For the latter is an operative method of activity, not a predetermined set of final truths. (LW13: 321)

Dewey's faith in the democratic planning can be found not only in his philosophical work but also in his political activism during the Great Depression and the New Deal era. Many of his statements on democratic 
socialism come from publications and activism linked to the People's Lobby (PL) and the League for Independent Political Action (LIPA). Even critics of Dewey's social theory point to the fact that groups such as the PL, LIPA and the Farmer-Labour Political Federation (FLPF) provided the politics that Dewey's '... ideals and his political theory demanded. These were organizations that showed Dewey's belief that the two dominant political parties of the United States were under the spell of bourgeois democracy and were unable and unwilling to stand up to the power of capital. These groups therefore campaigned to create new forms of alliance between agricultural farmers, the working class and the middle class in the pursuit and hope of founding a new third political party. Moreover, Dewey's pursuit of radical 'third party' politics within the United States sought to create the very organizations that could help educate and inform the eclipsed public he had talked about since the 1920s, and also sought to 'invest them with the power to define their interests and reconstruct the state' (Westbrook 1991: 452).

\section{Democracy and equality}

The details of Dewey's democratic socialism have always stoked debate amongst Deweyan scholars and interlocutors. In the essay the 'End of Leninism', Richard Rorty, perhaps Dewey's most infamous philosophical interpreter of the twentieth century, states that Dewey was calling for nothing short of the wide-scale replacement of the market economy. Rorty goes on to argue that such thought, in the light of the latter half of the twentieth century and the fall of organized communism, was simply outdated and proven to be a political and moral dead end (Rorty 1998: 329n15). On the other hand, Robert Westbrook (2005: 171) - Dewey's most famous historical interpreter - believes Rorty's own interpretation went too far and concealed the fact that Dewey's vision of democratic socialism was of a 'semi-socialist' market economy regulated in the interests of the least well off. It is beyond the remit of this book to settle the debate about the details of Dewey's vision of 
the democratic socialism and its political economy. ${ }^{6}$ However, we can make the argument as to why Dewey sought to achieve democratic socialism in the first place. At the heart of Dewey's vision of political economy were ideas about the need to secure economic equality to ensure the ethical commitment of democracy as a way of life and the diffusion of democratic habits that would facilitate social intelligence. This was because the Great Society had unleashed forces which, when interpreted through the lens of bourgeois democracy and its ideas of liberty, could perpetually undermine the democratic way of life and the use of social intelligence.

Dewey's ideas about the relationship between economic and political equality can be gleaned from his critique of the New Deal. Castigating it as an inadequate 'half-way house' between unregulated capitalism and democratic socialism, Dewey saw that the New Deal as ideological enterprise designed 'to save the profit system from itself' (LW9: 289). The reforms of Roosevelt, Dewey argued, were nothing more than temporary measures which as 'sure as night follows day' would inevitability lead back to restoring the power and privilege of bourgeois democracy (LW9: 77). By 1939, Dewey was even more adamant that the 'profit' system of capitalism was incapable of democratic ends:

The means have to be implemented by a social-economic system that establishes and uses the means for the production of free human beings associating with one another on terms of equality. Then and then only will these means be an integral part of the end, not frustrated and self-defeating, bringing new evils and generating new problems.

(LW13: 320)

The question then becomes why did Dewey believe that the socialeconomic system he encountered was incapable of producing free human beings associating with one another on terms of equality? And how did this result in Dewey arguing for democratic socialism within the confines of the Great Society?

The answers to these questions are best illustrated in Dewey's reconstruction of liberalism and liberty in Liberalism and Social Action (LW11) and a whole swathe of essays written throughout the 
Great Depression. In these works, Dewey puts forward the idea that 'liberalism' and its idea of liberty had become a much-confused concept and departed from its initial meaning (LW11: 5). If we recall the discussion of philosophical liberalism in Chapter 3, Dewey highlighted that the advent of bourgeois democracy had seen the ideas of liberty, individualism and democracy become fused with the ideal of laissezfaire capitalism (LW11: 250). Dewey, however, took this conception of liberty and individualism to task. Outlining the fact that liberty is not a static or general concept, Dewey contends that liberty is best conceived as 'power, the effective power to do specific things'. This demand for power was always historically located and based on the distribution of power that 'exists at the time.' The system of liberties is always just a 'system of restraints or controls that exists at that time'. As a result, Dewey argued that there was no such thing as 'liberty or effective power of an individual group, or class' except in relation to the 'liberties, the effective powers, of other individuals, groups and classes. This revealed the social nature of liberty, where 'the liberties that any individual actually has depended upon the distribution of powers and liberties' engendered by the legal, political and economic structures of society (LW11: 361-2).

Dewey argued that when liberty was rightfully taken as a historically relative concept, philosophical liberalism's rendering of 'liberty', 'individualism' and 'democracy' as historically chained to ideas of laissez-faire capitalism was simply a denial of the historical relativity of liberty. More to the point, such an ahistorical idea of liberty concealed the fact that ideas that once espoused freedom, bringing about the 'glorious revolution' of 1688 and eighteenth- and nineteenth-century democratic revolts against oligarchical government, had become a form of 'pseudoliberalism' that ossified an illiberal form of social organization (LW11: 287, 291). The ideas of liberty, individualism and democracy that were tied to laissez-faire capitalism were now undeniably unfit for purpose and stood against the very ideas they were supposed to represent:

... laissez-faire liberalism is played out, largely because of the fruits of its own policies. Any system that cannot provide elementary security 
for millions has no claim to the title of being organized in behalf of the liberty and the development of individuals. (LW11: 287)

Dewey was adamant that the entire meaning of liberalism and liberty must now be reconstructed to help facilitate creative democracy and the habits of social intelligence in the midst of the Great Society. To this end, Dewey recovered what he called the 'formula of early democratic political liberalism' that located the relationship between equality and liberty and recognized the historical relativity associated with obtaining this goal. This conception of democratic liberty, which in the hands of Dewey was another name for the democratic way of life, viewed that all humans are and were 'born free and equal'. This was not a foolish belief in the equality of individual endowments but rather the belief that political equality was the product of social institutions, laws, and customs and habits. Within this idea of liberty, social institutions and laws should always act 'as such to secure and establish equality for all' in order to perpetuate the democratic ideal. This recovering of the 'formula of early democratic political liberalism' revealed that equality, liberty and fraternity were not incompatible but rather that the 'actual liberties of one human being depend upon the powers of action that existing institutional arrangements accord to other individuals' (LW11: 369-70). To secure its ethical commitment, the democratic way of life therefore always demanded a historically relative democratic distribution of liberties (Westbrook 1991: 436).

When Dewey utilized this 'formula of early democratic political liberalism, it became clear to him that an economic reorganization of the Great Society must be at the centre of a democratic distribution of liberties. Whilst Dewey did not discount the importance of economic relations across history, the context of the Great Society now meant that industry, banking and commerce had reached a point where 'private business enterprise' affected so many people in 'deep and enduring ways' that all 'business' was held a potential 'public interest'. Since the 'consequences of business' were now social, society must itself look after 'the industrial and financial causes of these consequences' (LW11: 287). This in turn formed the rationale of Dewey's ideas that a 
reconstructed liberalism would have to centre on a form of democratic socialism in order to live up to the democratic way of life because the social consequences of laissez-faire liberalism, namely its cultural and economic inequality, now prevented liberty for all:

... the ends which liberalism has always professed can be attained only as control of the means of production and distribution is taken out of the hands of individuals who exercise powers created socially for narrow individual interests. The ends remain valid. But the means of attaining them demand a radical change in economic institutions and the political arrangements based upon them. These changes are necessary in order that social control of forces and agencies socially created may accrue to the liberation of all individuals associated together in the great undertaking of building a life that expresses and promotes human liberty. (LW11: 367)

What is pivotal to note here, however, is that Dewey's reconstructed liberalism along democratic socialist lines makes a distinct statement about the role of economic equality in the maintenance of the democratic way of life and the possibility of social intelligence within the context of the Great Society. The industrial-technological revolutions of the Great Society and their control by 'finance-capitalism' through the ideology of laissez-faire liberalism had given liberty of action to certain citizens and groups with '.. abilities of acquiring property and to the employment of that wealth in further acquisitions'. The favouring of such abilities not only created an insidious link between capital and industry and science, but also saw the creation of economic inequalities that impoverished political democracy and secured the 'monopoly of power in the hands of the few to control the opportunities of the wide masses and to limit their free activities in realizing their natural capacities' (LW11: 369-70). Dewey stressed that this meant that a democratic distribution of liberties was now only possible through the establishment of economic equality:

The democratic ideal that unites equality and liberty is, on the other hand, recognition that actual and concrete liberty of opportunity and action is dependant upon equalization of the political and economic 
conditions under which individuals are alone free in fact, not in some abstract metaphysical way. The tragic breakdown of democracy is due to the fact that the identification of liberty with the maximum of unrestrained individualistic action in the economic sphere, under the institutions of capitalistic finance, is as fatal to the realization of liberty for all as it is fatal to the realization of equality. It is destructive of liberty for the many precisely because it is destructive of genuine equality of opportunity. (LW11:370)

This was because the genie of the industrial-technological revolutions and the ideas of laissez-faire liberalism could not simply be put back in the lamp. It was inevitable, Dewey argued, that if such ideas and practices were left unchecked and remained hegemonic that they would seize the fruits of industrial-technological revolutions and generate a form of economic inequality that would perpetually nullify any chance of creative democracy:

The drift of nominal democracy from the conception of life which may properly be characterized as democratic has come about under the influence of a so-called rugged individualism that defines the liberty of individuals in terms of the inequality bred by existing economic-legal institutions. In so doing, it puts almost exclusive emphasis upon those natural capacities of individuals that have power to effect pecuniary and materialistic acquisitions. For our existing materialism, with the blight to which it subjects the cultural development of individuals, is the inevitable product of the exaggeration of the economic liberty of the few at the expense of the all-around liberty of the many. And, I repeat, this limitation upon genuine liberty is the inevitable product of the inequality that arises and must arise under the operations of institutionally established and supported finance-capitalism. (LW11:371) ${ }^{7}$

If one took liberty to mean the 'power to act' and a democratic conception of liberty to mean the 'power to act equally', then it became clear to Dewey that only an equal distribution of power within economic circles would now facilitate genuine political equality within the context of the Great Society. Dewey thus declared that the 'future of 
democracy' within the context of cultural matrix of the Great Society now centred on how democracy could be made secure in a context where most people have the 'minimum' of control over the conditions of their own subsistence. The democratic way of life would now have to be twined with the idea of using 'political action to bring about equalisation of economic conditions in order that the equal right of all to free choice and free action be maintained' (LW13: 178, 300). When this is taken into consideration, Dewey's arguments for democratic socialism read as nothing more as the means to achieve a democratic distribution of liberty (power) within the Great Society:

Power today resides in control of the means of production, exchange, publicity, transportation and communication. Whoever owns them rules the life of the country, not necessarily by intention, not necessarily by deliberate corruption of the nominal government, but by necessity. Power is power and must act, and it must act according to the nature of the machinery through which it operates. In this case, the machinery is business for private profit through private control of banking, land, industry, reinforced by command of the press, press agents and other means of publicity and propaganda. In order to restore democracy, one thing and one thing only is essential. The people will rule when they have power, and they will have power in the degree they own and control the land, the banks, the producing and distributing agencies of the nation. Ravings about Bolshevism, Communism, Socialism are irrelevant to the axiomatic truth of this statement. They come either from complaisant ignorance or from the deliberate desire of those in possession, power and rule to perpetuate their privilege. (LW9: 76-77)

Whatever the debate about the details of Dewey's democratic socialism and its political economy, it becomes apparent that Dewey believed that economic security and equality for the masses would have to be secured in order for democracy as a way of life to live up to its own ethical commitment within the context of the Great Society. Unlike Marxist positions, which posited a metaphysical argument about alienation to call for a wholesale change of the economic system (LW13: 116-35), Dewey did not turn to democratic socialism because he believed it would 
reconcile man with himself but because he saw such ideas and practices as the best means to achieving a democratic distribution of liberties in the midst of the industrial-technological revolutions of the Great Society and laissez-faire liberalism. Moreover, this move towards securing 'greater measures of economic freedom for the mass of people' was not an end in itself but rather was the means to secure political equality and the 'means' within the Great Society to secure the 'cultural freedom' which would facilitate the emergence of the Great Community and allow the human '... development through science, art and unconstrained human intercourse' (LW11: 254). This cultural freedom was about securing the diffusion of habits that would help facilitate the use of social intelligence. However, the chief point here is that Dewey put forward a historically rooted argument that such cultural freedom was now only possible through mutually reinforcing forms of equality of political opportunity and equality of economic outcome. ${ }^{8}$

\section{Global democracy and equality}

The obvious question that arises from the discussion of Dewey's idea about the relationship between economic equality and democracy in the Great Society surrounds its global connotations. After all, the Great Society was shorthand not simply for American corporate capitalism but also for the complex global capitalist economy that was initiated by the long nineteenth century and the First Great Globalization. Would Dewey's work then lend itself towards a global democratic distribution of liberties and a global equalization of economic conditions? Moreover, can Dewey's work on democracy and equality offer us a form of global justice?

This question has most recently been approached by Phillip Deen (2013), who has attempted to see if philosophical pragmatism and, in particular, Dewey's work can offer an account of global distributive justice. Taking the process of social intelligence and its use to solve moral problems as the essential commitment of philosophical pragmatism, 
Deen outlines that for writers such as Dewey 'a just global order is one that provides the conditions for fruitful democratic inquiry on matters crossing boundaries, both physical and conceptual, between states or peoples. Moreover, Deen contends that pragmatism, and in particular Dewey's work, develops two ends of a continuum between the ideal and non-ideal conditions for producing a just international order (Deen 213: 112-16). These two ends are:

1. A just order that addresses concrete problems at the international level - such as global climate change, gross economic inequality between nations and human rights - that utilizes the social intelligence and its experimental method to form moral value and social policy between nation states and publics within and between nation states. The use of ideal models here would be to test 'experimentally' in order to show how they can solve global problems.

2. Certain practical conditions must be brought about to ensure that social intelligence can take place. These include institutional arrangements, such as rights of expression and freedom of information and assembly, that facilitate social intelligence and lessening of the distorted effects of poverty and inequality.

Deen goes on to argue that 'long experience' has determined the 'necessary conditions' for social intelligence and allows us to assert that 'relatively stable ends for inquiry' require us to now 'free people from great want, oppression or ignorance' (Deen 2013: 116). ${ }^{9}$ Deen prefigures his paper with two disclaimers. One is that his work does not take into account historical development of Dewey's writings on international politics. The second is that his work is 'unabashedly speculative' (Deen 2013: 112). In response to this, we can say that Deen's work need not be speculative as creative democracy through social intelligence was what Dewey wished to come to pass both at home and aboard. As Dewey stated in 1944:

Just as genuinely peaceful relations amongst nations cannot be secured save by systematic intelligent study, foresight and planning, so with 
democracy within a nation. The development of procedures and techniques, legal, political, economic, which will foster and sustain equal freedom for all, instead of irresponsible freedom for a few and constraint and depression for the many, is the outstanding social problem of our age. It requires the kind of vigilance which is positively expressed in study, planning, experimentation, to establish institutions which will make equality of opportunity and hence freedom realities for all - not slogans to be manipulated by a class for its one separate interest. (LW17: 462)

Moreover, had Deen examined Dewey's work on international politics and the need for creative democracy at the international level, he would have found arguments that both support and extend beyond his own ideas. Dewey believed that the ethical commitment of democracy as a way of life and social intelligence must be supported at the international level. However, Dewey did not just throw his weight behind a regime that would secure a global minimalism that would only free people from great want, oppression or ignorance. Rather, Dewey extended his arguments about equality and democracy within the confines of bourgeois democracy at home into the international arena of the Great Society.

As Dewey outlined, the ideas of philosophical liberalism about equality and liberty seemed even more hegemonic at the international level. This regime of 'free-trade' was 'hopelessly defective' because it failed to see how 'intelligent supervision' and 'positively controlling action' were needed to maintain 'equality of conditions' (MW11: 141). This state of affairs had led to a game of 'rivalry and competition in industry and nationalistic ambitions' that had 'extended to become a deadly competition in all the means of destruction' (LW17: 454). Nations and their publics now routinely neglected the social aspects of their interdependence and saw global interdependence as a zero-sum game:

Bad results work both ways. In order to compete with other nations, a competition artificially made harder by the present system of barriers, labour standards are lowered at home. Then other nations find that 
unless wages are reduced at home and labour speeded up, they are at a disadvantage. Their standards are put in peril. We have made almost universal the inquiry of Cain: "Am I my brother's keeper?" We have erected indifference and antagonism into a positive virtue, although we know in domestic affairs that depression of one group and section, means loss to all others. (LW11: 262)

As early as Dewey's post-First World War writings, one can glean a sense of disdain for such liberal ideas about international free trade and the global economy and how such ideas expressed themselves through imperialism, asymmetric North/South relations and large-scale inequalities. As Dewey outlined in 1918 on the subject of President Wilson's new diplomacy, the League of Nations and economic freedom, these material inequalities ultimately prohibited the extension of democracy as a way of life at the international level:

It has been demonstrated that more is needed to secure freedom and equality of conditions between individuals than to declare them legally all free and equal, while leaving them to unrestricted competition with one another. Immense inequality of power is compatible with formal equality. The same thing will surely develop with respect to any merely legal equality among nations. Certain nations have a tremendous superiority in population, natural resources, technical progress in industry, command of credit, and shipping. Nothing better calculated to develop inequality of trade relationship among nations could well be found than a system which set up a nominal mathematical equality and then threw matters practically into the hands of the present big nations. (MW 11: 139)

Dewey's idea of equality between nations thus did not centre on free trade within a liberal-capitalist global economy but a system of trade and commerce that would eradicate imperialism and inequality in its economic, political and cultural manifestations. This resembled a form of democratic socialism at international level and would require, as Dewey outlined at the end of the First World War, a global economy that was democratically controlled, and international organizations that could deal with matters such as 'equality of labour standards, the 
regulation of shipping... of food, raw materials and immigrants, and above all else the exportation of capital and distribution of the available credit of the world. Equality of trade conditions means equalisation of conditions' (MW11: 139-40). Global democracy for Dewey would therefore require that rich nations of the world give up their hegemonic control of the global economy and allow the self-government and development of wealth amongst poor nations (Westbrook 1991: 237). ${ }^{10}$

What the above reveals is that Dewey believed that the practice of creative democracy through social intelligence between nations was unlikely to transpire within a global regime based on liberal capitalism. This is quite simply because the global economic regime based on the tenets of liberal capitalism, as it was at home within the nation state, was antithetical towards creating or allowing a context in which such a state of affairs could arise. In short, a liberal-capitalist global economy would always be focused on profit, imperialism and empire rather than democracy as a way of life. To provide the conditions that would allow all members of the world to potentially live the democratic way of life and participate in social intelligence would require furnishing conditions for political equality and of economic development (political, educational, scientific, industrial) that would allow for democratic habits of social intelligence to become widespread both at home and abroad. Thus, Dewey did not believe that transforming the Great Society into the Great Community at international level was simply about managing the economic interdependence of nations or creating equal political standing between nation states. Rather, given the forces of industry the Great Society had unleashed, what was needed was a fundamental reformation of the global liberal-capitalist economy and a form of political and economic equality at the global level. This democratic distribution of liberties in the international arena would allow countries to embark upon pathways that would allow them to acquire and utilize the habits of social intelligence and in turn facilitate the democratic way of life between countries. ${ }^{11}$

Towards the end of the Second World War, Dewey repeated this argument that democracy at the international level also required 
a democratic distribution of liberties and that to achieve such a distribution of liberties required a fundamental reconfiguration of ideas of equality and liberty and political economy in the international arena:

The opportunities for us, the people of the United States, will be tremendous. A means for widely distributing the world's goods among all nations must be provided ... A way of carrying health and education and a higher standard of life to the utmost corners of the earth must be assured. The mechanical means have already been produced by science and invention. Physically, the world is now one and interdependent. Only human beings - interested that men everywhere have a society of peace, of security, of opportunity, of growth in cooperation - can assure its being made morally one. A genuine democratic victory will be achieved only when it is made by democratic governments for the well-being of the common people of the earth. (LW17: 131-2)

When it comes to issues of global distributive justice, we can say that Dewey was far more radical than critics and supporters are willing to give him credit for. Dewey seems to have been a democratic socialist, both at home and abroad, because the inefficiency of wasting our human resources was not just an American issue but also a global issue. Wasting of such resources not only was a moral problem, which denied various individuals and publics access to the democratic way of life, but was symptomatic of how the Great Society was split between the two worlds of the pre-scientific and the scientific. This not only cost everyone the potential of individual intelligences, who perished each year to the effects of stratification, but such a social order also negatively effected 'effective intelligence' through the cultural subjugation of the great mass of people and denied society and the world at the large the fruits of using socialized intelligence to conduct its moral affairs.

For Dewey, bourgeois democracy and liberal capitalism, both at home and abroad, were thus morally repugnant and physically inefficient; a society which had managed to utilize the natural power of steam, electricity and machines but failed to fully engage, enlist and release available human energy (LW13: 312). ${ }^{12}$ The overriding point 
of this chapter, however, is that Dewey did not believe such problems would be solved without a fundamental reordering of political economy, both at home and abroad, along the lines of economic equality. The gains of the Great Society had quite simply created a situation, where it would be impossible to create the 'enduring opportunity for productive and creative activity and all that signifies for the development of the potentialities of human nature' without 'remaking the profit system' in the first instance (LW13: 318). ${ }^{13}$ 
John Narayan - 9781526101020

Downloaded from manchesterhive.com at 04/26/2023 11:43:12AM 